This document is the Accepted Manuscript version of a Published Work that appeared in final form in ACS Applied Materials and Interfaces, copyright (c) American Chemical Society after peer review and technical editing by the publisher. To access the final edited and published work see:

https://dx.doi.org/10.1021/acsami. 9b23206. 


\section{MOF-Beads containing inorganic nanoparticles for the simultaneous removal of multiple heavy metals from water}

Gerard Boix, ${ }^{\dagger}$ Javier Troyano, ${ }^{\dagger}$ Luis Garzón-Tovar, ${ }^{\dagger}$ Ceren Camur, ${ }^{\dagger}$ Natalia Bermejo, ${ }^{+}$Amirali Yazdi, $^{+}$Jordi Piella, ${ }^{\dagger}$ Neus G. Bastus, ${ }^{\dagger}$ Victor F. Puntes, ${ }^{\dagger}{ }^{\ddagger}$ Inhar Imaz ${ }^{*+}$ and Daniel Maspoch*+, ${ }^{*}$

+Catalan Institute of Nanoscience and Nanotechnology (ICN2), CSIC and The Barcelona Institute of Science and Technology, Campus UAB, Bellaterra, 08193, Barcelona, Spain.

¥/CREA, Pg. Lluıs Companys 23, 08010, Barcelona, Spain

KEYWORDS: Metal-Organic Frameworks, Composite, Inorganic Nanoparticles, Metal removal, Water treatment.

ABSTRACT: Pollution of water with heavy metals is a global environmental problem whose impact is especially severe in developing countries. Among water-purification methods, adsorption of heavy metals has proven to be simple, versatile and cost-effective. However, there is still a need to develop adsorbents with a capacity to remove multiple metal pollutants from the same water sample. Herein we report the complementary adsorption capacities of metal-organic frameworks (MOFs; here, UiO-66 and UiO-66(SH) 2 ) and inorganic nanoparticles (iNPs; here, cerium-oxide NPs) into composite materials. These adsorbents, which are spherical microbeads generated in one step by continuous-flow spray-drying, efficiently and simultaneously remove multiple heavy metals from water, including $\mathrm{As}(\mathrm{III}$ and $\mathrm{V}), \mathrm{Cd}(\mathrm{II}), \mathrm{Cr}(\mathrm{III}$ and $\mathrm{VI}), \mathrm{Cu}(\mathrm{II}), \mathrm{Pb}(\mathrm{II})$ and $\mathrm{Hg}(\mathrm{II})$. We further show that these microbeads can be used as packing material in a prototype of a continuous-flow water treatment system, in which they retain their metal-removal capacities upon regeneration with a gentle acidic treatment. As proof-of-concept, we evaluated these adsorbents for purification of laboratory water samples prepared to independently recapitulate each of two strongly-polluted rivers: the Bone (Indonesia) and Buringanga (Bangladesh) rivers. In both cases, our microbeads reduced the levels of all the metal contaminants to below the corresponding permissible limits established by the World Health Organization (WHO). Moreover, we demonstrated the capacity of these microbeads to lower levels of $\mathrm{Cr}(\mathrm{VI})$ in a water sample collected from the Sarno River (Italy). Finally, to create adsorbents that could be magnetically recovered following their use in water purification, we extended our spraydrying technique to simultaneously incorporate two types of iNPs $\left(\mathrm{CeO}_{2}\right.$ and $\left.\mathrm{Fe}_{3} \mathrm{O}_{4}\right)$ into $\mathrm{UiO}-66(\mathrm{SH})_{2}$, obtaining $\mathrm{CeO}_{2} / \mathrm{Fe}_{3} \mathrm{O}_{4} @ \mathrm{UiO}-66-(\mathrm{SH})_{2}$ microbeads that adsorb heavy metals and are magnetically responsive. 


\section{INTRODUCTION}

Water pollution is a principal cause of health disorders worldwide. ${ }^{1-3}$ Increasing industrial activity, especially in developing countries, often involves contamination of water with soluble toxic metal-ion pollutants that readily accumulate in humans and animals. ${ }^{3,4}$ Exposure to heavy metals such as arsenic, cadmium, chromium, lead and mercury, even at trace levels, is especially pernicious to human health. ${ }^{5,6}$ Consequently, major efforts have been devoted to the development of water-treatment methods. Recently proposed strategies for wastewater purification include coagulation, filtration and chemical precipitation. However, these methods usually require complex instruments and large facilities, which in turn translate to high maintenance costs. Additionally, they have limited utility for removing pollutants at low concentrations and therefore, must often be combined with complementary methods.

One promising approach for water treatment is adsorption, which has been lauded for its simplicity, versatility, cost efficiency and effectiveness. ${ }^{7-9}$ Common adsorbents such as activated carbon, zeolites, clay minerals and natural fibers have been studied for the adsorptive removal of heavy metal ions. However, these materials suffer from drawbacks such as limited regeneration, slow sorption kinetics, relatively low thermal or chemical stability, and limited selectivity. ${ }^{10,11}$ Adsorbents for water purification must be able to simultaneously remove co-existing pollutants. Accordingly, they should remove as many different harmful metal ions as possible. ${ }^{12}$ An interesting strategy to develop such adsorbents is to combine different adsorbent materials, each with its respective functionality, into a single composite that shows broad-spectrum activity.

Metal-organic frameworks (MOFs), which are porous ordered structures exhibiting large specific surface areas, have recently garnered much attention as adsorbent materials, given their high adsorption capacity and chemical/structural tunability. ${ }^{13-18} \mathrm{An}$ exemplary case of tunable MOFs is that of the water-stable, zirconium-based, UiO-66 family, which, at their inorganic nodes or organic linkers, can be functionalized with moieties that strongly bind heavy-metal ions. For example, bare UiO-66 has been reported to remove $\mathrm{Cr}(\mathrm{VI})$ and $\mathrm{As}(\mathrm{V})$ from water, demonstrating adsorption capacities of $86 \mathrm{mg} / \mathrm{g}$ and $303 \mathrm{mg} / \mathrm{g}$, respectively. ${ }^{10,19}$ Moreover, once functionalized with thiourea groups, this MOF can adsorb various other metal ions, including As(V) (303 mg/g), Hg(II) (769 mg/g), Pb(II) (232 mg/g), Cr(III) $(117 \mathrm{mg} / \mathrm{g})$ and $\mathrm{Cd}(\mathrm{II})(49 \mathrm{mg} / \mathrm{g}) .^{10,20}$ Similarly, functionalization of UiO-66 with thiol groups enhances uptake of $\mathrm{Hg}(\mathrm{II})$, even in strongly acidic aqueous solutions and vapors, ${ }^{21}$ up to $236 \mathrm{mg} / \mathrm{g}$ and increases adsorption of As(III) up to $40 \mathrm{mg} / \mathrm{g}^{22}$

Another class of material that has been widely studied as adsorbents is inorganic nanoparticles (iNPs), which exhibit high activity and specificity towards heavy-metal ions..$^{23,24}$ For example, cerium oxide $\left(\mathrm{CeO}_{2}\right) \mathrm{NPs}$ have exhibited excellent adsorption capacities for the following metal ions in water: $\mathrm{Pb}(\mathrm{II})$ (128 mg/g), Cr(VI) (122 mg/g), Cd(II) (93 mg/g) and As(V) (17 mg/g). ${ }^{25-27}$ Importantly, some iNPs can be easily magnetically retrieved from solution, thus obviating impractical alternatives such as filtering. However, a drawback of iNPs is their tendency to aggregate, which significantly compromises their adsorption efficiency.

One way to mitigate the iNP-aggregation problem is to incorporate iNPs into the porous matrices of other materials. ${ }^{28}$ Among porous materials, MOFs have surfaced as an attractive partner for iNPs, not only to prevent iNP-aggregation and to facilitate their recovery after adsorption process, but also for their remediation capabilities. To date, most MOF/iNP composites have been developed for catalysis. ${ }^{29}$ However, within the field of pollutant removal, iNPs have been combined with MOFs to yield MOF/iNP adsorbents with added functionalities such as magnetism ${ }^{30,31}$ or photocatalytic degradation. 12,32,33 
Herein we report new composite microbeads (hereafter, iNP@MOF-Beads) for simultaneous removal of various metals from water, which we obtained by incorporating inorganic nanoparticles (iNPs) into MOFs via a one-step spray-drying process (Fig. 1). As iNPs, we used $\mathrm{CeO}_{2}$ and as MOFs, we used the water-stable Zr-MOFs UiO-66 or UiO-66-(SH) 2 . We tested the resultant composite microbeads $\left(\mathrm{CeO}_{2} @ U i \mathrm{U}-66\right.$ and $\left.\mathrm{CeO}_{2} @ U i \mathrm{UiO}-66-(\mathrm{SH})_{2}\right)$ for purification of synthetic river-water samples prepared as mimics of two polluted rivers, and of a real field sample from another polluted river. Furthermore, we evaluated our iNP@MOF-Beads as packing material in fixed-bed, continuous-adsorption columns. Finally, we developed magnetic $\mathrm{CeO}_{2} / \mathrm{Fe}_{3} \mathrm{O}_{4} @ U i \mathrm{UiO}-66-(\mathrm{SH})_{2}$ microbeads by simultaneously incorporating $\mathrm{CeO}_{2}$ and $\mathrm{Fe}_{3} \mathrm{O}_{4} \mathrm{NPs}$ into UiO-66-(SH) 2 .

\section{MATERIALS AND METHODS}

Zirconium (IV) propoxide solution (70\% (w/w)) in 1-propanol; cerium (III) nitrate; sodium meta arsenite; sodium arsenate dibasic heptahydrate; cadmium (II) nitrate tetrahydrate; chromium (III) nitrate nonahydrate; chromium (VI) oxide; copper (II) nitrate hemi(pentahydrate); lead (II) nitrate; mercury (II) chloride; terephthalic acid; phosphoric acid; diethyl 2,5-dihydroxyterephthalate, polyvinylpyrrolidone (PVP, $\mathrm{M}_{\mathrm{w}} \sim 10,000$ ), 1,4-diazabicyclo[2.2.2]octane; dimethylthiocarbomoyl chloride and hexamethylenetetramine were purchased from Sigma Aldrich. $\mathrm{N}, \mathrm{N}$-dimethylformamide (DMF), methanol and acetone were purchased from Fisher Scientific. All the reagents were used without further purification. Deionized water, obtained with a Milli- ${ }^{\circledR}$ system $(18.2 \mathrm{M} \Omega \cdot \mathrm{cm})$, was used in all adsorption experiments. $\mathrm{Fe}_{3} \mathrm{O}_{4}$ nanoparticles $(8-\mathrm{nm} ; 1 \mathrm{~g} / \mathrm{L}$ ) dispersed in an aqueous solution of PVP (1 mg/mL) was purchased from Applied Nanoparticles. 2,5-dimercaptoterephthalic acid was synthesized according to a reported procedure. ${ }^{34} \mathrm{X}$-ray powder diffraction (XRPD) patterns were collected on an X'Pert PRO MPDP analytical diffractometer (Panalytical) at $45 \mathrm{kV}$ and $40 \mathrm{~mA}$ using CuK $\alpha$ radiation $(\lambda=1.5419 \AA)$. Nitrogen adsorption and desorption measurements were performed at $77 \mathrm{~K}$ using an Autosorb-IQ-AG analyzer (Quantachrome Instruments). Field-emission scanning electron microscopy (FE-SEM) images were collected on a Magellan $400 \mathrm{~L}$ scanning electron microscope (FEI) at an acceleration voltage of $5.0 \mathrm{KV}$ and a Quanta 650F scanning electron microscope (FEI) at an acceleration voltage of $20.0 \mathrm{KV}$, using aluminum as support. Transmission Electron Microscopy (TEM) images and EDX composition profiles were collected on a Tecnai G2 F20 microscope (FEI) at $200 \mathrm{KV}$. ${ }^{1} \mathrm{H}$ NMR spectra were acquired in a Bruker Avance III 400SB NMR spectrometer. Inductively Coupled Plasma - Optical Emission Spectroscopy (ICP-OES) measurements were performed on an Optima 4300DV (Perkin-Elmer) instrument.

\section{Synthesis of PVP-functionalized $\mathrm{CeO}_{2}$ nanoparticles}

Cerium-oxide nanoparticles were synthesized according to modified published procedures..$^{35,36}$ In a typical experiment, equal volumes of aqueous $\mathrm{Ce}\left(\mathrm{NO}_{3}\right)_{3}(75 \mathrm{~mL}, 0.04 \mathrm{M})$ and aqueous hexamethylenetetramine $(75 \mathrm{~mL}, 0.50 \mathrm{M})$ were mixed at room temperature and the resultant solution was left at $25^{\circ} \mathrm{C}$ for 48 hours under mild stirring. $\mathrm{CeO}_{2}$ nanoparticles were formed by the controlled oxidation of $\mathrm{Ce}$ (III) to $\mathrm{Ce}$ (IV) under alkaline conditions, which subsequently precipitated in the form of insoluble $\mathrm{CeO}_{2}$ species. $4 \mathrm{~g}$ of PVP in $200 \mathrm{~mL}$ of water was added dropwise to a stirring solution of the iNP and the flask was left to rest overnight at room temperature. Then, $800 \mathrm{~mL}$ of acetone was added and the solution was left at room temperature for 24 hours without stirring, leading to precipitation of the NPs. The supernatant was removed by decanting and then, the iNPs were washed three times with DMF. Finally, they were redispersed in DMF to afford a colloidal solution of $\mathrm{CeO}_{2} \mathrm{NPs}(1 \mathrm{mg} / \mathrm{mL})$. The average size of the synthesized $\mathrm{CeO}_{2} \mathrm{NPs}$ was $12 \mathrm{~nm} \pm 2.5 \mathrm{~nm}$.

\section{Synthesis of 2,5-dimercaptoterephthalic acid}


2,5-dimercaptoterephthalic acid was synthesized according to an adapted literature procedure ${ }^{34}$. Briefly, a solution of diethyl 2,5-dihydroxyterephthalate $(0.08 \mathrm{~mol}, 20 \mathrm{~g})$ in $300 \mathrm{~mL}$ of degassed DMF was introduced into a $500 \mathrm{~mL}$ three-neck round bottom flask under Ar atmosphere and cooled down to $0^{\circ} \mathrm{C}$. Then, 1,4-diazabicyclo[2.2.2] octane $(0.31 \mathrm{~mol}, 35.2 \mathrm{~g})$ was added under magnetic stirring and the solution was left stirring for 10 minutes. Dimethylthiocarbomoyl chloride $(0.32 \mathrm{~mol}, 39 \mathrm{~g})$ was then slowly added to the mixture, the suspension was allowed to warm to room temperature and then, stirred for 24 hours under Ar atmosphere. The product was precipitated out with $500 \mathrm{~mL}$ water, filtered and washed extensively with water (yield: $31 \mathrm{~g}, 95 \%$ ). The diethyl 2,5bis[(dimethylcarbamothioyl)oxy]terephthalate obtained was dried and stored under Ar atmosphere. The obtained product ( $8 \mathrm{mmol}, 3.25 \mathrm{~g}$ ) was heated under Ar atmosphere at $215{ }^{\circ} \mathrm{C}$ for 1 hour. The resulting brown paste was cooled down to $70{ }^{\circ} \mathrm{C}$ and dissolved in $100 \mathrm{~mL}$ of EtOH. The solution was cooled down to room temperature, gradually affording fine brown crystals. The crystals were filtered off, yielding diethyl 2,5-bis(dimethylthiocarbamoylsulfanyl)terephthalate $(2.75 \mathrm{~g}$, yield $85 \%)$. A solution of the previously obtained product $(6 \mathrm{mmol}, 2.6 \mathrm{~g})$ in a degassed $1.3 \mathrm{M}$ solution of $\mathrm{KOH}$ in $\mathrm{EtOH} / \mathrm{H}_{2} \mathrm{O}(1: 1,80 \mathrm{~mL})$ was refluxed for 3 hours under Ar atmosphere. The reaction mixture was cooled down to $0^{\circ} \mathrm{C}$ and $\mathrm{HCl}(37 \% \mathrm{w} / \mathrm{w}, 30 \mathrm{~mL})$ was added slowly. The precipitated 2,5dimercaptoterephthalic acid was collected by filtration, washed extensively with water, dried under dynamic vacuum and stored under $\operatorname{Ar}\left(1.29 \mathrm{~g}\right.$, yield 93\%). ${ }^{1} \mathrm{H}-\mathrm{NMR}$ confirmed formation of the desired product (Fig. S1).

\section{Synthesis of UiO-66, $\mathrm{CeO}_{2} @ U i O-66$, UiO-66-(SH) ${ }_{2}$ and $\mathrm{CeO}_{2} @ U i O-66-(\mathrm{SH})_{2}$}

All materials were synthesized by a slightly modified version of a previously reported spray-drying method ${ }^{37}$. Briefly, terephthalic acid $(0.6 \mathrm{mmol}, 100 \mathrm{mg})$, glacial acetic acid $(3 \mathrm{~mL})$, a solution of $\mathrm{CeO}_{2}$ NPs in DMF (1 mg/mL; $8.5 \mathrm{~mL})$ and a $70 \%(\mathrm{w} / \mathrm{w})$ solution of zirconium (IV) propoxide $\left(\operatorname{Zr}\left(\mathrm{OPr}^{\mathrm{n}}\right)_{4}\right)$ in 1propanol $(0.5 \mathrm{mmol}, 280 \mu \mathrm{L}$ ) were sequentially added to a flask containing $40 \mathrm{~mL}$ of DMF. The resulting mixture was injected into a coil-flow reactor (inner diameter: $3 \mathrm{~mm}$ ) at a feed rate of $2.4 \mathrm{~mL} / \mathrm{min}$ at $115^{\circ} \mathrm{C}$. The resulting pre-heated solution was then spray-dried at $180^{\circ} \mathrm{C}$, at a flow rate of $336 \mathrm{~mL} / \mathrm{min}$, using a B-290 Mini Spray-Dryer (BUCHI Labortechnik; spray cap hole diameter: $0.5 \mathrm{~mm}$ ). The resulting solid was dispersed in DMF, washed twice with DMF and ethanol, and finally dried for $12 \mathrm{~h}$ at $85^{\circ} \mathrm{C}$ under vaccum. Encapsulation efficiency was determined by ICP-OES and was found to be $4.0 \% \mathrm{w} / \mathrm{w}$ (93\% encapsulation yield) for the $\mathrm{CeO}_{2} @$ UiO-66 composite. The thiolated materials were synthetized following the same procedure, except that terephthalic acid was replaced with 2,5dimercaptoterephthalic acid (proportional molar ratio) and plain DMF instead of a $\mathrm{CeO}_{2} \mathrm{NP}$ dispersion, when appropriate. For the $\mathrm{CeO}_{2} @ U i \mathrm{U}-66-(\mathrm{SH})_{2}$ composite, the level of encapsulation of $\mathrm{CeO}_{2} \mathrm{iNPs}$ was calculated to be $3.3 \% \mathrm{w} / \mathrm{w}$ ( $87 \%$ encapsulation yield).

\section{Synthesis of $\mathrm{CeO}_{2} / \mathrm{Fe}_{3} \mathrm{O}_{4} @ U i O-66-(\mathrm{SH})_{2}$}

This composite was synthesized following the above procedure with minor modifications. Briefly, 2,5dimercaptoterephthalic acid $(0.6 \mathrm{mmol}, 138 \mathrm{mg})$, glacial acetic acid $(3 \mathrm{~mL})$, a dispersion of $\mathrm{CeO}_{2}$ and $\mathrm{Fe}_{3} \mathrm{O}_{4}$ iNPs in DMF $\left(1 \mathrm{mg} / \mathrm{mL}\right.$ of $\mathrm{CeO}_{2}$ and $2 \mathrm{mg} / \mathrm{mL}$ of $\left.\mathrm{Fe}_{3} \mathrm{O}_{4} ; 8.5 \mathrm{~mL}\right)$ and a $70 \%(\mathrm{w} / \mathrm{w})$ solution of $\mathrm{Zr}\left(\mathrm{OPr}^{\mathrm{n}}\right)_{4}$ in 1-propanol $(0.5 \mathrm{mmol}, 280 \mu \mathrm{L})$ were sequentially added to a flask containing $40 \mathrm{~mL}$ of DMF. The resulting mixture was spray-dried, and the resultant solid was washed and dried, as above. Encapsulation of the nanoparticles was monitored by TEM imaging and ICP-OES analysis. The encapsulation efficiencies were $3.0 \% \mathrm{w} / \mathrm{w}$ (79\% encapsulation yield) for the $\mathrm{CeO}_{2}$ iNPs and $9.3 \% \mathrm{w} / \mathrm{w}$ (97\% encapsulation yield) for the $\mathrm{Fe}_{3} \mathrm{O}_{4}$ iNPs.

\section{Metal-adsorption studies}




\section{Single-metal adsorption}

1 mg of UiO-66, $\mathrm{CeO}_{2} @$ UiO-66, UiO-66-(SH) 2 or $\mathrm{CeO}_{2} @$ UiO-66-(SH) 2 was added to a $50 \mathrm{~mL}$ Falcon centrifugation tube containing $30 \mathrm{~mL}$ of a $100 \mathrm{ppb}$ aqueous solution $(\mathrm{pH} 5)$ of one of the following metal ions: $\mathrm{As}(\mathrm{III}), \mathrm{As}(\mathrm{V}), \mathrm{Cd}(\mathrm{II}), \mathrm{Cr}(\mathrm{III}), \mathrm{Cr}(\mathrm{VI}), \mathrm{Cu}(\mathrm{II}), \mathrm{Pb}(\mathrm{II})$ or $\mathrm{Hg}(\mathrm{II})$ (i.e. each tube corresponded to a single metal). The Falcon tubes were sonicated for 2 minutes to ensure homogeneous dispersion and then, agitated for 3 hours at $30 \mathrm{rpm}$ in a rotary agitator at room temperature. Afterwards, the samples were centrifuged, and the supernatant was collected through a $200 \mu \mathrm{m}$ syringe filter and finally, stored at $4{ }^{\circ} \mathrm{C}$ in the dark until ICP-OES analysis.

\section{Multi-metal adsorption}

$1 \mathrm{mg}$ of $\mathrm{CeO}_{2} @$ UiO-66-(SH) $)_{2}$ was loaded into a $50 \mathrm{~mL}$ Falcon centrifugation tube containing $30 \mathrm{~mL}$ of a $100 \mathrm{ppb}$ aqueous solution (pH 5) of all of the following metal ions: $\mathrm{As}(\mathrm{III}), \mathrm{As}(\mathrm{V}), \mathrm{Cd}(\mathrm{II}), \mathrm{Cr}(\mathrm{III}), \mathrm{Cr}(\mathrm{VI})$, $\mathrm{Cu}(\mathrm{II}), \mathrm{Pb}(\mathrm{II})$ and $\mathrm{Hg}$ (II) (i.e. the tube contained all the metals, each at $100 \mathrm{ppb}$ ). The rest of the procedure was the same as for the single-pollutant analysis (see above).

\section{Continuous-flow adsorption and regeneration}

The packed-powder column prototype was made by compacting $10 \mathrm{mg}$ of $\mathrm{CeO}_{2} @ \mathrm{UiO}-66-(\mathrm{SH})_{2}$ into a glass column and subsequently capping the column with cotton wool. Afterwards, $5 \mathrm{~mL}$ of Milli-Q water was passed through the column. For comparative adsorption, $30 \mathrm{~mL}$ of a solution containing $100 \mathrm{ppb}$ each of $\mathrm{As}(\mathrm{III}$ and $\mathrm{V}), \mathrm{Cd}(\mathrm{II}), \mathrm{Cr}(\mathrm{III}$ and $\mathrm{VI}), \mathrm{Cu}(\mathrm{II}), \mathrm{Pb}(\mathrm{II})$ and $\mathrm{Hg}(\mathrm{II})$ was passed through the column at a flow rate of $1.3 \mathrm{~mL} / \mathrm{min}$. The filtered metal solution was collected and analyzed by ICPOES. The adsorption-desorption cycling experiments comprised an adsorption step, whereby $30 \mathrm{~mL}$ of a solution (pH 5) containing $100 \mathrm{ppb}$ each of $\mathrm{As}(\mathrm{III}), \mathrm{As}(\mathrm{V}), \mathrm{Cd}(\mathrm{II}), \mathrm{Cr}(\mathrm{III}), \mathrm{Cr}(\mathrm{VI}), \mathrm{Cu}(\mathrm{II}), \mathrm{Pb}(\mathrm{II})$ and $\mathrm{Hg}(\mathrm{II})$ ions was filtered through the column; and a desorption step, in which $100 \mathrm{~mL}$ of a $250 \mathrm{mM}$ solution of $\mathrm{NaH}_{2} \mathrm{PO}_{4}{ }^{38}(\mathrm{pH} 5)$ was passed through the column. The cycle was repeated ten times and all collected filtrates were analyzed by ICP-OES to follow $\mathrm{Hg}$ (II). The breakthrough curve experiment was performed using the same column setup described above. $2340 \mathrm{~mL}$ of a $100 \mathrm{ppb} \mathrm{Cr}$ (III) solution were passed through the column collecting aliquots at different time intervals, which were then analyzed by ICPOES.

\section{Synthetic river-water samples}

Water samples that recapitulated the Buringanga River and the Bone River were separately prepared based on reported values (ppb) of metal pollutants in each river. ${ }^{39,40}$ Briefly, Milli-Q water solutions containing the necessary metal ions was prepared at both $\mathrm{pH} 5$ and at the natural $\mathrm{pH}$ of each river: $\mathrm{pH}$ 6.6 (using $\mathrm{HNO}_{3}$ ) for the Buringanga River and $\mathrm{pH} 7.5$ (using $\mathrm{NaOH}$ ) for the Bone River. The solutions were stored at $4{ }^{\circ} \mathrm{C}$ in the dark until use.

\section{River-water metal adsorption}

Similarly to in the adsorption procedures described above, 1 mg of $\mathrm{CeO}_{2} @ U i \mathrm{O}-66-(\mathrm{SH})_{2}$ was loaded into $50 \mathrm{~mL}$ Falcon centrifugation tubes containing $30 \mathrm{~mL}$ samples (Bone River, Buringanga River or Sarno River), either at $\mathrm{pH} 5$ or at the corresponding natural $\mathrm{pH}$. The rest of the procedure was the same as for the single-metal and multi-metal analyses (see above). The experiment was repeated with $1 \mathrm{mg}$ of $\mathrm{CeO}_{2} @ U i \mathrm{O}-66$, but only for the Bone River sample. The samples of the three rivers at their natural $\mathrm{pH}$ were also filtered through the packed-powder column prototype. The procedure was the same as for the multiple-pollutant analysis using the column prototype (see above). 
Insert figure 1

\section{Magnetically-functionalized adsorption}

$0.3 \mathrm{mg}$ of $\mathrm{CeO}_{2} / \mathrm{Fe}_{3} \mathrm{O}_{4} @$ UiO-66-(SH) 2 was added to an aqueous solution $(10 \mathrm{~mL}, \mathrm{pH}$ 5) containing 100 ppb each of $\mathrm{As}(\mathrm{III}), \mathrm{As}(\mathrm{V}), \mathrm{Cd}(\mathrm{II}), \mathrm{Cr}(\mathrm{III}), \mathrm{Cr}(\mathrm{VI}), \mathrm{Cu}(\mathrm{II}), \mathrm{Pb}(\mathrm{II})$ and $\mathrm{Hg}(\mathrm{II})$. The suspension was agitated for 3 hours at 30 rpm in a rotary agitator at room temperature. The $\mathrm{CeO}_{2} / \mathrm{Fe}_{3} \mathrm{O}_{4} @ \mathrm{UiO}-66-(\mathrm{SH})_{2}$ microbeads were then recovered with a neodymium magnet, and the supernatant was collected through a 200 $\mu \mathrm{m}$ syringe filter and stored at $4^{\circ} \mathrm{C}$ in the dark until ICP-OES analysis.

\section{Adsorption calculations}

In each of the adsorption tests, the maximum uptake capacity $\left(L_{M}\right)$ of the microbeads was calculated as:

$$
L_{M}=\frac{C_{0} \times V}{M}
$$

where $C_{0}$ is the initial concentration of the solution; $V$, the volume loaded into the Falcon tube; and $M$, the mass of MOF used for the adsorption.

The pollutant-loading level $(L)$ of the microbeads was calculated as:

$$
L=\frac{\left(C_{0}-C_{f}\right) \times V}{M}
$$

, where $C_{f}$ is the final measured concentration.

And finally, the percentage of pollutant adsorbed from each sample was calculated as follows:

$$
\% \text { Adsorption }=\frac{L}{L_{M}} \times 100
$$

\section{RESULTS AND DISCUSSION}

\section{Synthesis and characterization}

The UiO-66 and $\mathrm{CeO}_{2} @ U i O-66$ microbeads, and their corresponding thiol-functionalized derivatives UiO-66-(SH) 2 and $\mathrm{CeO}_{2} @$ UiO-66-(SH) $)_{2}$, were synthesized following a continuous-flow spray-drying methodology previously reported by our group (Fig. 1a). ${ }^{37,41}$ In a typical synthesis, a solution containing the corresponding MOF precursors and dispersed $\mathrm{CeO}_{2} \mathrm{NPs}$ (for the composites) were injected into a coil-flow reactor and subsequently spray-dried, leading to the formation of dense microscale beads in the form of dry powders.

FE-SEM of all four samples revealed the formation of spherical beads (average size: $1.5 \mu \mathrm{m} \pm 1.0 \mu \mathrm{m}$ ) formed by nanocrystals of UiO-66 and UiO-66-(SH) 2 (Fig. 1b). X-ray powder diffraction (XRPD) on the beads revealed a pure, crystalline, UiO-66-type framework (Fig. S2). Moreover, high-angle annular dark-field scanning transmission electron microscopy (HAADF-STEM) on $\mathrm{CeO}_{2} @ U i O-66$ and on $\mathrm{CeO}_{2} @$ UiO-66-(SH) ${ }_{2}$ confirmed the encapsulation of disperse $\mathrm{CeO}_{2}$ NPs inside them (Fig. 1b). The 
samples were digested with $5 \% \mathrm{HF}$, and the supernatant was filtered, and then used for quantification of the $\mathrm{CeO}_{2}$ iNP content by ICP-OES. The iNP-content values found were $4.0 \%(\mathrm{w} / \mathrm{w})$ for $\mathrm{CeO}_{2} @ U i O-$ 66 (encapsulation yield: 93\%) and 3.3\% (w/w) for $\mathrm{CeO}_{2} @ U i \mathrm{O}-66-(\mathrm{SH})_{2}$ (encapsulation yield: 87\%).

The porosity of all four samples was confirmed by nitrogen adsorption analysis at $77 \mathrm{~K}$, from which the following BET surface areas were found: $945 \mathrm{~m}^{2} / \mathrm{g}$ (UiO-66), $597 \mathrm{~m}^{2} / \mathrm{g}$ (UiO-66-(SH) 2 ), $747 \mathrm{~m}^{2} / \mathrm{g}$ $\left(\mathrm{CeO}_{2} @ U i \mathrm{O}-66\right)$ and $539 \mathrm{~m}^{2} / \mathrm{g}\left(\mathrm{CeO}_{2} @ U i \mathrm{U}-66-(\mathrm{SH})_{2}\right)$ (Fig. S3). The values for the pristine MOFs are consistent with literature reports. ${ }^{42}$ The collected isotherms were found to be type IV (IUPAC classification) isotherms presenting hysteresis loops. This behavior is typical of MOF beads made by spray-drying and can be attributed to the presence of some mesoporosity derived from the nanocrystal assembly that forms the beads.

\section{Metal-adsorption capacity}

We evaluated the potential of our microbeads as adsorbents for the most prevalent heavy-metal pollutants in industrial wastewater: $\mathrm{As}(\mathrm{III}$ and $\mathrm{V}), \mathrm{Cd}(\mathrm{II}), \mathrm{Cr}(\mathrm{III}$ and $\mathrm{VI}), \mathrm{Cu}(\mathrm{II}), \mathrm{Pb}(\mathrm{II})$ and $\mathrm{Hg}(\mathrm{II})$. To this end, each sample (bead concentration: $0.03 \mathrm{mg} / \mathrm{mL}$ ) was incubated in aqueous solutions ( $\mathrm{pH}$ 5) of the different metal ions ( $100 \mathrm{ppb}$ ) for 3 hours under continuous stirring. Note that the $\mathrm{pH}$ of the aqueous solutions was fixed at 5 to prevent precipitation of the metal ions during the adsorption studies. The metal-ion concentration of $100 \mathrm{ppb}$ was selected because it falls within the range of concentrations for metal ions found in contaminated waters (see, for example Table 1). After 3 hours, the beads were separated from the aqueous solutions and the amount of metal ions remaining in the supernatants was evaluated by ICP-OES.

The adsorption capacity values for all metal ions are shown in Figure $2 \mathrm{a}$ and Table S1, revealing two clear trends. Firstly, the pendant thiol groups confer a functional benefit: in all cases, relative to UiO66, the UiO-66-(SH $)_{2}$ demonstrated superior uptake of all the metal ions except As(V). The anomaly for $\mathrm{As}(\mathrm{V})$ uptake can be rationalized according to its distinct adsorption mechanism, in which the ions are adsorbed by the zirconium clusters through $\mathrm{Zr}$-O-As coordination bonds, ${ }^{10,22}$ which are more easily accessible without the steric hindrance of the thiol groups. The second trend is that incorporation of $\mathrm{CeO}_{2}$ NPs into MOF microbeads enhances adsorption of both $\mathrm{As}(\mathrm{III})$ and $\mathrm{Cr}(\mathrm{IV})$, as expected from the previously reported activity and selectivity of these NPs towards these metal ions. ${ }^{25,43}$ This functional gain is important, as As(III) and $\mathrm{Cr}$ (IV) are highly toxic pollutants and, especially in the case of the latter, exhibit high mobility, ${ }^{4,44}$ making them a high priority for removal from industrial wastewater. Moreover, compared to the case of other metals, efficient removal of these two metal ions from water usually takes longer, suffers from lower uptakes and requires a previous chemical conversion. ${ }^{45}$

Insert figure 2

Altogether, our results prompted us to select $\mathrm{CeO}_{2} @ U i \mathrm{UiO}-66-(\mathrm{SH})_{2}$ for a test of simultaneous adsorption of all the metals. To this end, $\mathrm{CeO}_{2} @ U i \mathrm{UiO}-66-(\mathrm{SH})_{2}$ microbeads were incubated in an aqueous mixture containing all the aforementioned metal ions at a concentration of $100 \mathrm{ppb}$ each (Fig. 2b). The $\mathrm{CeO}_{2} @ U i \mathrm{U}-66-(\mathrm{SH})_{2}$ microbeads removed 99 ppb Pb(II) (99\%), 99 ppb Cu(II) (99\%), 98 ppb Hg(II) (98\%), 185 ppb Cr(III and VI) (93\%), 87 ppb Cd(II) (87\%), 111 ppb As(III and V) (56\%). Thus, $\mathrm{CeO}_{2} @$ UiO-66-(SH) ${ }_{2}$ simultaneously captured all the different metal ions while demonstrating the same adsorption capacity for each one as in the previous single-metal adsorption experiments. 
In addition to strongly adsorbing target pollutants from water, MOF-based adsorbents must also be stable and not release their component metal ions (in our case, $\mathrm{Zr}$ (IV) plus $\mathrm{Ce}$ (IV), to form the MOF and the iNP) into the water. Accordingly, we also investigated the presence of these metal ions in the aqueous solutions of the adsorption experiments. $\mathrm{Zr}(\mathrm{IV})$ and $\mathrm{Ce}$ (IV) were not detected in any of the samples, confirming the stability of the microbeads. Moreover, and further confirming the stability of the microbeads, XRPD after the metal-adsorption experiments indicated that all the microbeads had retained the crystallinity of the parent samples (Fig. S2).

\section{iNP@MOF -Beads as packing material in a column for continuous-flow removal of metals from water}

Once we had demonstrated that our microbeads effectively remove heavy metal ions from water, we next evaluated their performance as packing material in a purification column. To this end, $10 \mathrm{mg}$ of $\mathrm{CeO}_{2} @$ UiO-66-(SH) 2 were packed into a 5 mm-diameter glass column (Fig. 3a), through which $30 \mathrm{~mL}$ of an aqueous solution (pH 5) of $\mathrm{As}(\mathrm{III}), \mathrm{As}(\mathrm{V}), \mathrm{Cd}(\mathrm{II}), \mathrm{Cr}(\mathrm{III}), \mathrm{Cr}(\mathrm{VI}), \mathrm{Cu}(\mathrm{II}), \mathrm{Pb}(\mathrm{II})$ and $\mathrm{Hg}(\mathrm{II})$ (100 ppb each) was passed through at a flow rate of $1.3 \mathrm{~mL} / \mathrm{min}$. The filtrate was analyzed by ICP-OES, revealing the following removal rates for each metal: $\mathrm{Pb}$ (II) (99\%); $\mathrm{Hg}$ (II) (99\%); $\mathrm{Cu}(\mathrm{II})$ (99\%); $\mathrm{Cd}$ (II) (85\%); $\mathrm{Cr}$ (III and VI) (84\%); As(III and V) (69\%) (Fig. 3b). Thus, after purification by the microbeads, the final remaining concentration of each metal in the water sample was: $\mathrm{Pb}$ (II) and $\mathrm{Hg}$ (II) (less than $0.25 \mathrm{ppb}$ ); $\mathrm{Cu}(\mathrm{II})$ (0.3 ppb); $\mathrm{Cd}(\mathrm{II})$ (15 ppb); $\mathrm{Cr}(\mathrm{III}$ and VI) (32 ppb); and As(III and V) (62 ppb). Remarkably, the concentration of all metals in the water sample could be reduced down to $0.25 \mathrm{ppb}$ by passing this latter sample twice more through the column (Fig. 3b). In addition, using $\mathrm{Cr}$ (III) as a model metal ion, we performed a breakthrough curve with a $10 \mathrm{mg}$ packed powder bed of $\mathrm{CeO}_{2} @ \mathrm{UiO}-66-(\mathrm{SH})_{2}$, a feed solution with a $\mathrm{Cr}$ (III) concentration of $100 \mathrm{ppb}$, and a flow rate of $1.3 \mathrm{~mL} / \mathrm{min}$ (Fig. S4). From the obtained data, we could determine a breakthrough time $\left(10 \% \mathrm{C}_{0}\right)$ of 231 minutes $(300.6 \mathrm{~mL})$ and an exhaust time $\left(90 \% \mathrm{C}_{0}\right)$ of 1239 minutes $(1610.4 \mathrm{~mL})$. The degree of saturation was calculated to be $45 \%,{ }^{46}$ and the maximum loading capacity of the column was $82.7 \mathrm{mg}$ of $\mathrm{Cr}$ (III) per $\mathrm{g}$ of adsorbent. This capture capacity value compares favorably with other fixed bed adsorption studies found in the literature. $^{47}$

Insert figure 3

An important aspect to be considered when using a new adsorbent in packed columns is its regeneration, which in our case, corresponds to metal-ion desorption from $\mathrm{CeO}_{2} @$ UiO-66-(SH) 2 . To explore this property, we tested the $\mathrm{CeO}_{2} @ U i O-66-(\mathrm{SH})_{2}$-packed column over three adsorption/desorption cycles. The adsorption step comprised filtering $30 \mathrm{~mL}$ of an aqueous solution $(\mathrm{pH} 5)$ of all the studied metals (100 ppb each).The desorption (regeneration) step entailed passing $100 \mathrm{~mL}$ of a $250 \mathrm{mM}$ aqueous solution of $\mathrm{H}_{2} \mathrm{PO}_{4}{ }^{-}(\mathrm{pH} 5)$ through the column at a flow rate of 1.3 $\mathrm{mL} / \mathrm{min}$. ICP-OES analysis of the collected filtrate revealed almost complete desorption (>96\%) and recovery of most the metal ions ( $\mathrm{As}(\mathrm{III}$ and $\mathrm{V}), \mathrm{Cd}(\mathrm{II}), \mathrm{Cr}(\mathrm{III}$ and $\mathrm{VI}, \mathrm{Cu}(\mathrm{II})$ and $\mathrm{Pb}(\mathrm{II}))$ ) and high desorption (>91\%) and recovery of $\mathrm{Hg}(\mathrm{II})$ (Fig. 4a,b). To further demonstrate the regeneration of $\mathrm{CeO}_{2} @ U$ UiO-66$(\mathrm{SH})_{2}$, this adsorption/desorption cycle was repeated ten times and all the collected filtrates were analyzed by ICP-OES to determine the desorption of $\mathrm{Hg}^{2+}$. Interestingly, the corresponding uptake rates were similar among the ten cycles, meaning that the regeneration process was sufficient to maintain the adsorption capacity of our microbeads (Fig. 4b). 
Insert figure 4

\section{Metal removal in synthetic and real river-water samples}

Having preliminarily demonstrated the metal-adsorption capacities of our microbeads, we next evaluated them in test cases corresponding to known cases of river pollution. Firstly, synthetic riverwater samples were prepared to independently recapitulate the Buringanga River ${ }^{39}$ (Bangladesh) and the Bone River ${ }^{40}$ (Indonesia), both of which contain metal ions at concentrations well-above the WHO standards (Table 1). Specifically, the Buringanga River is contaminated with $\mathrm{Cd}(\mathrm{II}), \mathrm{Cr}(\mathrm{III}), \mathrm{Cu}(\mathrm{II})$ and $\mathrm{Pb}(\mathrm{II})$, whereas the Bone River is contaminated with $\mathrm{Hg}(\mathrm{II}), \mathrm{As}(\mathrm{V})$ and $\mathrm{Pb}(\mathrm{II})$. Initially, $\mathrm{CeO}_{2} @ U$ UiO-66$(\mathrm{SH})_{2}$ microbeads (bead concentration: $0.03 \mathrm{mg} / \mathrm{mL}$ ) were incubated in the synthetic samples for 3 hours under continuous stirring. Then, the microbeads were separated from the water samples and the concentration of metal ions remaining in the treated water river samples was determined by ICPOES. Note that the adsorption was tested at the natural $\mathrm{pH}$ of each river ( $\mathrm{pH} 6.6$ for the Buringanga River and $\mathrm{pH} 7.5$ for the Bone River) as well as at pH 5, for comparison. Table 1 shows the heavy-metal ion capture capacity of the $\mathrm{CeO}_{2} @ U$ UiO-66-(SH) $)_{2}$ microbeads.

Insert table 1

For the Buringanga River sample at $\mathrm{pH} 6.6$, the microbeads removed more than $98 \%$ of $\mathrm{Cd}(\mathrm{II}), \mathrm{Cu}(\mathrm{II})$ and $\mathrm{Pb}(\mathrm{II})$ ions and $69 \%$ of $\mathrm{Cr}(\mathrm{III})$ ions; thus, the microbeads had reduced the concentration of each metal to below the WHO limits (Table 1). At pH 5, the microbeads exhibited slightly different performance, adsorbing more than $98 \%$ of the $\mathrm{Cr}(\mathrm{III}), \mathrm{Cu}(\mathrm{II})$ and $\mathrm{Pb}$ (II) ions, while removing only $65 \%$ of the $\mathrm{Cd}(\mathrm{II})$ (Table 1). Consequently, the remaining concentration of $\mathrm{Cd}(\mathrm{II})$ in the supernatant (23 ppb) was above the corresponding WHO limit.

For the Bone River sample at pH 5, the $\mathrm{CeO}_{2} @ U i \mathrm{O}-66-(\mathrm{SH})_{2}$ microbeads captured more than $99 \%$ of $\mathrm{Hg}(\mathrm{II})$ and $\mathrm{Pb}(\mathrm{II})$, leaving behind only $2.5 \mathrm{ppb}$ and $1.4 \mathrm{ppb}$, respectively both under the WHO limits. However, it could not efficiently capture As(V), leaving behind $109 \mathrm{ppb}$, which is well above the corresponding WHO limit. At Bone's natural pH 7.5, the $\mathrm{CeO}_{2} @ U$ UiO-66-(SH) 2 microbeads adsorbed 99\% of $\mathrm{Pb}(\mathrm{II})$ and $31 \% \mathrm{As}(\mathrm{V})$, which is still above the WHO limit. Fortunately, UiO-66@CeO microbeads adsorbed $62 \%$ of the $\mathrm{As}(\mathrm{V})$, leaving behind $46 \mathrm{ppb}$ of the latter, which, while above the WHO limit, is below the water standards concentration for Indonesia (Table 1). Note that the adsorption of $\mathrm{Hg}(\mathrm{II})$ at $\mathrm{pH} 7.5$ could not be analyzed, as $\mathrm{Hg}$ (II) begins to precipitate out at $\mathrm{pH} 6$ and above. At such $\mathrm{pH}$ values, the $\mathrm{Hg}(\mathrm{II})$ precipitates are typically removed by filtration or flocculation systems.

To evaluate our $\mathrm{CeO}_{2} @$ UiO-66-(SH) 2 microbeads for purification of real field samples from rivers, we also tested them for removal of metals from a sample collected from the Sarno River, in Italy (pH 7.2). Although the Sarno River currently meets the WHO standards for metal-ion levels in potable water, its $\mathrm{Cr}(\mathrm{VI})$ levels presently exceed those of other European rivers. The Sarno River sample contained 11 ppb of $\mathrm{Cr}(\mathrm{VI})$ and minuscule amounts of $\mathrm{As}(\mathrm{III})(0.9 \mathrm{ppb})$ and $\mathrm{Cu}(\mathrm{II})(3.2 \mathrm{ppb})$, of which the $\mathrm{CeO}_{2} @ U i \mathrm{O}-$ $66-(\mathrm{SH})_{2}$ microbeads captured $37 \%, 55 \%$ and $99 \%$, respectively (Table 1 ). 
Next, we studied the continuous-flow removal of metals from the three river samples using the column containing packed $\mathrm{CeO}_{2} @ U i \mathrm{U}-66-(\mathrm{SH})_{2}$ microbeads $(10 \mathrm{mg})$. To this end, $30 \mathrm{~mL}$ of each river sample was passed through the column at a flow rate of $1.3 \mathrm{~mL} / \mathrm{min}$. For the Buringanga River sample, the column removed more than $99 \%$ of $\mathrm{Cd}(\mathrm{II}), \mathrm{Cu}(\mathrm{II})$ and $\mathrm{Pb}(\mathrm{II})$ ions and $90 \%$ of $\mathrm{Cr}(\mathrm{III})$ ions; and for the Bone River sample, it adsorbed $99 \%$ of the $\mathrm{Pb}(\mathrm{II})$ and $86 \%$ of the $\mathrm{As}(\mathrm{V})$. In both cases, purification through the column reduced the concentration of each metal to below the WHO limits (Table 1). In the case of the Sarno River sample, the column removed $99 \%$ of all $\mathrm{Cr}(\mathrm{VI}), \mathrm{As}(\mathrm{III})$ and $\mathrm{Cu}(\mathrm{II})$.

\section{Magnetically functionalized iNP@MOF-Beads}

Finally, having demonstrated that our microbeads can remove various heavy metals from water, we sought to explore the possibility of conferring them with magnetism, such they could be magnetically removed after water purification. To this end, we turned again to spray-drying, which can be exploited to incorporate multiple classes of nanoparticles into MOF microbeads. Thus, $\mathrm{CeO}_{2}$ and $\mathrm{Fe}_{3} \mathrm{O}_{4} \mathrm{NPs}_{\mathrm{N}}$ were simultaneously incorporated into UiO-66- $(\mathrm{SH})_{2}$ to afford a magnetically responsive microbead, $\mathrm{CeO}_{2} / \mathrm{Fe}_{3} \mathrm{O}_{4} @ U$ UiO-66-(SH) $)_{2}$ (Fig. 5a). FE-SEM and XRPD confirmed the formation of spherical microbeads built of UiO-66-(SH) 2 nanocrystals (Fig. $5 \mathrm{~b}$ and Fig. S5). Furthermore, HAADF-STEM, EDX and ICP-OES analyses revealed successful incorporation of both types of iNPs into the composite microbeads at the following content levels $\left(\mathrm{w} / \mathrm{w}\right.$ ): $3.0 \%$ for $\mathrm{CeO}_{2}$ and $9.3 \%$ for $\mathrm{Fe}_{3} \mathrm{O}_{4}$ (Fig. $5 \mathrm{~b}$ and Fig. S6).

Insert figure 5

We then tested the adsorption capacity of the $\mathrm{CeO}_{2} / \mathrm{Fe}_{3} \mathrm{O}_{4} @ U i \mathrm{UiO}-66-(\mathrm{SH})_{2}$ microbeads by incubating $(0.03 \mathrm{mg} / \mathrm{mL})$ them in a water sample containing $100 \mathrm{ppb}$ each of $\mathrm{As}(\mathrm{III}), \mathrm{As}(\mathrm{V}), \mathrm{Cd}(\mathrm{II}), \mathrm{Cr}(\mathrm{III}), \mathrm{Cr}(\mathrm{VI})$, $\mathrm{Cu}(\mathrm{II}), \mathrm{Pb}(\mathrm{II})$ and $\mathrm{Hg}(\mathrm{II})$, under continuous stirring. After 3 hours, the microbeads were separated out from the water sample by approaching a neodymium magnet to the water sample for 5 minutes (Fig. $5 c)$, and the amount of metal ions remaining in the treated water sample was evaluated by ICP-OES. Remarkably, the microbeads showed comparable metal-ion adsorption capacity to that of the original non-magnetic microbeads, $\mathrm{CeO}_{2} @ U i O-66-(\mathrm{SH})_{2}$ (Fig. 5d).

\section{CONCLUSIONS}

We have designed, developed and tested iNP@MOF composite microbeads as adsorbents for removal of heavy metal ions from water. The spherical microbeads are formed in one step by continuous-flow spray-drying. They efficiently and simultaneously remove various metal ions from water, including $\mathrm{As}(\mathrm{III}$ and $\mathrm{V}), \mathrm{Cd}(\mathrm{II}), \mathrm{Cr}(\mathrm{III}$ and $\mathrm{VI}), \mathrm{Cu}(\mathrm{II}), \mathrm{Pb}(\mathrm{II})$ and $\mathrm{Hg}(\mathrm{II})$, are stable during water purification, and can be regenerated by a gentle acidic treatment. We also successfully evaluated the best-performing of these microbeads, UiO-66-(SH) $@ \mathrm{CeO}_{2}$, as packing material in a continuous-flow column for water purification. We further confirmed the efficiency of CeO2@UiO-66-(SH)2 by testing it in synthetic and real river-water samples. For the samples that recapitulated the Bone River and the Buringanga River, treatment with our microbeads reduced the levels of most of the harmful metals to below the WHO limits; and for the Sarno River sample, it significantly reduced the relatively high content of $\mathrm{Cr}(\mathrm{VII})$. Finally, we explored the idea of conferring our microbeads with magnetism. Harnessing the versatility of spray-drying, we simultaneously incorporated two types of iNPs, $\mathrm{CeO}_{2}$ and $\mathrm{Fe}_{3} \mathrm{O}_{4}$, into UiO-66-(SH) to obtain $\mathrm{CeO}_{2} / \mathrm{Fe}_{3} \mathrm{O}_{4} @$ UiO-66-(SH) 2 . The resultant magnetic microbeads demonstrate similar metaladsorption capacity to the original non-magnetic microbeads and can easily be removed from treated 
water by a magnet. Given their ready formation and tunability, we are confident that such iNP@MOFBeads will prove utile in future water-purification applications.

\section{ASSOCIATED CONTENT}

\section{Supporting information}

The supporting information is available free of charge on the ACS Publications website at DOI: 10.1021/acsami.0x00000.

Additional figures include H-NMR spectra of the synthetized ligand; XRPD spectra of the studied materials; BET analysis of the studied materials; Table of the removal efficiency for single pollutant experiments; XRPD of the magnetic composite material; EDX analysis of the magnetic composite material

\section{Author information}

\section{Corresponding author}

*E-mail: daniel.maspoch@icn2.cat, inhar.imaz@icn2.cat

\section{ORCID}

Daniel Maspoch: 0000-0003-1325-9161

Inhar Imaz: 0000-0002-0278-1141

\section{Notes}

The authors declare no competing financial interest.

\section{ACKNOWLEDGEMENTS}

This work was supported by the Spanish MINECO (project RTI2018-095622-B-I00), the Catalan AGAUR (project 2017 SGR 238), and the ERC, under the EU-FP7 (ERC-Co 615954). It was also funded by the CERCA Program/Generalitat de Catalunya. ICN2 is supported by the Severo Ochoa program from the Spanish MINECO (Grant No. SEV-2017-0706).

\section{REFERENCES}

(1) Bakker, K. Water Security: Research Challenges and Opportunities. Science 2012, 337, 914 915.

(2) Dos Santos, C. E.; Dal Pizzol, V. I.; Aragão, S. C.; Filho, A. R.; Marques, F. M. Vasculite c-ANCA Relacionada Em Paciente Com Retocolite Ulcerativa: Relato de Caso. Rev. Bras. Reumatol. 2013, 53 441-443.

(3) Gleick, P. H. Global Freshwater Resources: Soft-Path Solutions for the 21st Century. Science 2003, 302 1524-1528.

(4) Tchounwou, P. B.; Yedjou, C. G.; Patlolla, A. K.; Sutton, D. J. Molecular, Clinical and Environmental Toxicology. 2012, 101, 1-30.

(5) WHO. Guidelines for Drinking-Water Quality: Incorporating 1st and 2nd Addenda, Vol. 1, Reccomendations - 3rd Edition. WHO Chron. 2008, 38, 668.

(6) Jaishankar, M.; Tseten, T.; Anbalagan, N.; Mathew, B. B.; Beeregowda, K. N. Toxicity, Mechanism and Health Effects of Some Heavy Metals. Interdiscip. Toxicol. 2014, 7, 60-72. 
(7) Li, B.; Zhang, Y.; Ma, D.; Shi, Z.; Ma, S. Mercury Nano-Trap for Effective and Efficient Removal of mercury(II) from Aqueous Solution. Nat. Commun. 2014, 5, 1-7.

(8) Huang, N.; Zhai, L.; Xu, H.; Jiang, D. Stable Covalent Organic Frameworks for Exceptional Mercury Removal from Aqueous Solutions. J. Am. Chem. Soc. 2017, 139, 2428-2434.

(9) Liu, B.; Jian, M.; Liu, R.; Yao, J.; Zhang, X. Highly Efficient Removal of arsenic(III) from Aqueous Solution by Zeolitic Imidazolate Frameworks with Different Morphology. Colloids Surfaces $A$ Physicochem. Eng. Asp. 2015, 481, 358-366.

(10) Wang, C.; Liu, X.; Chen, J. P.; Li, K. Superior Removal of Arsenic from Water with Zirconium Metal-Organic Framework UiO-66. Sci. Rep. 2015, 5, 1-10.

(11) Kumar, P.; Pournara, A.; Kim, K. H.; Bansal, V.; Rapti, S.; Manos, M. J. Metal-Organic Frameworks: Challenges and Opportunities for Ion-Exchange/sorption Applications. Prog. Mater. Sci. 2017, 86, 25-74.

(12) Hlongwane, G. N.; Sekoai, P. T.; Meyyappan, M.; Moothi, K. Simultaneous Removal of Pollutants from Water Using Nanoparticles: A Shift from Single Pollutant Control to Multiple Pollutant Control. Sci. Total Environ. 2019, 656, 808-833.

(13) Mon, M.; Bruno, R.; Ferrando-Soria, J.; Armentano, D.; Pardo, E. Metal-Organic Framework Technologies for Water Remediation: Towards a Sustainable Ecosystem. Journal of Materials Chemistry A. 2018, 6, 4912-4947.

(14) Kobielska, P. A.; Howarth, A. J.; Farha, O. K.; Nayak, S. Metal-organic Frameworks for Heavy Metal Removal from Water. Coord. Chem. Rev. 2018, 358, 92-107.

(15) Dhaka, S.; Kumar, R.; Deep, A.; Kurade, M. B.; Ji, S. W.; Jeon, B. H. Metal-organic Frameworks (MOFs) for the Removal of Emerging Contaminants from Aquatic Environments. Coord. Chem. Rev. 2019, 380, 330-352.

(16) Gao, Q.; Xu, J.; Bu, X. H. Recent Advances about Metal-organic Frameworks in the Removal of Pollutants from Wastewater. Coord. Chem. Rev. 2019, 378, 17-31.

(17) Wen, J.; Fang, Y.; Zeng, G. Progress and Prospect of Adsorptive Removal of Heavy Metal lons from Aqueous Solution Using Metal-organic Frameworks: A Review of Studies from the Last Decade. Chemosphere 2018, 201, 627-643.

(18) Mon, M.; Bruno, R.; Tiburcio, E.; Viciano-Chumillas, M.; Kalinke, L. H. G.; Ferrando-Soria, J.; Armentano, D.; Pardo, E. Multivariate Metal-Organic Frameworks for the Simultaneous Capture of Organic and Inorganic Contaminants from Water. J. Am. Chem. Soc. 2019, 141, 13601-13609.

(19) Noraee, Z.; Jafari, A.; Ghaderpoori, M.; Kamarehie, B.; Ghaderpoury, A. Use of Metal-Organic Framework to Remove Chromium (VI) from Aqueous Solutions. J. Environ. Heal. Sci. Eng. 2019, 1-9.

(20) Saleem, H.; Rafique, U.; Davies, R. P. Investigations on Post-Synthetically Modified UiO-66$\mathrm{NH} 2$ for the Adsorptive Removal of Heavy Metal lons from Aqueous Solution. Microporous Mesoporous Mater. 2016, 221, 238-244.

(21) Yee, K. K.; Reimer, N.; Liu, J.; Cheng, S. Y.; Yiu, S. M.; Weber, J.; Stock, N.; Xu, Z. Effective Mercury Sorption by Thiol-Laced Metal-Organic Frameworks: In Strong Acid and the Vapor Phase. J. Am. Chem. Soc. 2013, 135, 7795-7798. 
(22) Audu, C. O.; Nguyen, H. G. T.; Chang, C. Y.; Katz, M. J.; Mao, L.; Farha, O. K.; Hupp, J. T.; Nguyen, S. T. The Dual Capture of As V and As III by UiO-66 and Analogues. Chem. Sci. 2016, 7, 6492-6498.

(23) Simeonidis, K.; Mourdikoudis, S.; Kaprara, E.; Mitrakas, M.; Polavarapu, L. Inorganic Engineered Nanoparticles in Drinking Water Treatment: A Critical Review. Environ. Sci. Water Res. Technol. 2016, 2, 43-70.

(24) Prasse, C.; Ternes, T. Removal of Organic and Inorganic Pollutants and Pathogens from Wastewater and Drinking Water Using Nanoparticles - A Review. Nanoparticles in the Water Cycle: Properties, Analysis and Environmental Relevance; Springer Berlin Heidelberg, 2010; 55-79.

(25) Feng, Q.; Zhang, Z.; Ma, Y.; He, X.; Zhao, Y.; Chai, Z. Adsorption and Desorption Characteristics of Arsenic onto Ceria Nanoparticles. Nanoscale Res. Lett. 2012, 7, 1-8.

(26) Recillas, S.; Colón, J.; Casals, E.; González, E.; Puntes, V.; Sánchez, A.; Font, X. Chromium VI Adsorption on Cerium Oxide Nanoparticles and Morphology Changes during the Process. J. Hazard. Mater. 2010, 184, 425-431.

(27) Contreras, A. R.; Casals, E.; Puntes, V.; Komilis, D.; Sánchez, A.; Font, X. Use of Cerium Oxide (CeO2) Nanoparticles for the Adsorption of Dissolved Cadmium (II), Lead (II) and Chromium (VI) at Two Different pHs in Single and Multi-Component Systems. Glob. Nest J. 2015, 17, 536-543.

(28) Olivera, S.; Chaitra, K.; Venkatesh, K.; Muralidhara, H. B.; Inamuddin; Asiri, A. M.; Ahamed, M. I. Cerium Dioxide and Composites for the Removal of Toxic Metal lons. Environ. Chem. Lett. 2018, 16, 1233-1246.

(29) Falcaro, P.; Ricco, R.; Yazdi, A.; Imaz, I.; Furukawa, S.; Maspoch, D.; Ameloot, R.; Evans, J. D.; Doonan, C. J. Application of Metal and Metal Oxide Nanoparticles at MOFs. Coord. Chem. Rev. 2016, $307,237-254$.

(30) Zhao, G.; Qin, N.; Pan, A.; Wu, X.; Peng, C.; Ke, F.; Iqbal, M.; Ramachandraiah, K.; Zhu, J. Magnetic Nanoparticles@Metal-Organic Framework Composites as Sustainable Environment Adsorbents. J. Nanomater. 2019, 2019, 1-11.

(31) Sivashankar, R.; Sathya, A. B.; Vasantharaj, K.; Sivasubramanian, V. Magnetic Composite an Environmental Super Adsorbent for Dye Sequestration - A Review. Environ. Nanotechnology, Monit. Manag. 2014, 1-2, 36-49.

(32) Bedia, J.; Muelas-Ramos, V.; Peñas-Garzón, M.; Gómez-Avilés, A.; Rodríguez, J. J.; Belver, C. A Review on the Synthesis and Characterization of Metal Organic Frameworks for Photocatalytic Water Purification. Catalysts 2019, 9, 52.

(33) Santhosh, C.; Malathi, A.; Daneshvar, E.; Kollu, P.; Bhatnagar, A. Photocatalytic Degradation of Toxic Aquatic Pollutants by Novel Magnetic 3D-TiO2@HPGA Nanocomposite. Sci. Rep. 2018, 8, 1-15.

(34) Vial, L.; Ludlow, R. F.; Leclaire, J.; Pérez-Fernández, R.; Otto, S. Controlling the Biological Effects of Spermine Using a Synthetic Receptor. J. Am. Chem. Soc. 2006, 128 , 10253-10257.

(35) Zhang, F.; Jin, Q.; Chan, S.-W. Ceria Nanoparticles: Size, Size Distribution, and Shape. J. Appl. Phys. 2004, 95, 4319-4326.

(36) Zhang, F.; Chan, S. W.; Spanier, J. E.; Apak, E.; Jin, Q.; Robinson, R. D.; Herman, I. P. Cerium Oxide Nanoparticles: Size-Selective Formation and Structure Analysis. Appl. Phys. Lett. 2002, 80, 127129. 
(37) Yazdi, A.; Abo Markeb, A.; Garzón-Tovar, L.; Patarroyo, J.; Moral-Vico, J.; Alonso, A.; Sánchez, A.; Bastus, N.; Imaz, I.; Font, X.; Puntes, V; Maspoch, D. Core-Shell Au/CeO2 Nanoparticles Supported in UiO-66 Beads Exhibiting Full CO Conversion at $100{ }^{\circ} \mathrm{C}$. J. Mater. Chem. A 2017, 5, 13966-13970.

(38) Folens, K.; Leus, K.; Nicomel, N. R.; Meledina, M.; Turner, S.; Van Tendeloo, G.; Laing, G. Du; Van Der Voort, P. Fe304@MIL-101 - A Selective and Regenerable Adsorbent for the Removal of As Species from Water. Eur. J. Inorg. Chem. 2016, 2016, 4395-4401.

(39) Bhuiyan, M. A. H.; Dampare, S. B.; Islam, M. A.; Suzuki, S. Source Apportionment and Pollution Evaluation of Heavy Metals in Water and Sediments of Buriganga River, Bangladesh, Using Multivariate Analysis and Pollution Evaluation Indices. Environ. Monit. Assess. 2015, 187.

(40) Gafur, N. A.; Sakakibara, M.; Sano, S.; Sera, K. A Case Study of Heavy Metal Pollution in Water of Bone River by Artisanal Small-Scale Gold Mine Activities in Eastern Part of Gorontalo, Indonesia. Water (Switzerland) 2018, 10, 1-10.

(41) Garzón-Tovar, L.; Cano-Sarabia, M.; Carné-Sánchez, A.; Carbonell, C.; Imaz, I.; Maspoch, D. A Spray-Drying Continuous-Flow Method for Simultaneous Synthesis and Shaping of Microspherical High Nuclearity MOF Beads. React. Chem. Eng. 2016, 1, 533-539.

(42) Leus, K.; Perez, J. P. H.; Folens, K.; Meledina, M.; Van Tendeloo, G.; Du Laing, G.; Van Der Voort, P. UiO-66-(SH)2 as Stable, Selective and Regenerable Adsorbent for the Removal of Mercury from Water under Environmentally-Relevant Conditions. Faraday Discuss. 2017, 201, 145-161.

(43) Xiao, H.; Ai, Z.; Zhang, L. Nonaqueous Sol-Gel Synthesized Hierarchical CeO2 Nanocrystal Microspheres as Novel Adsorbents for Wastewater Treatment. J. Phys. Chem. C 2009, 113, 1662516630.

(44) Marinho, B. A.; Cristóvão, R. O.; Boaventura, R. A. R.; Vilar, V. J. P. As(III) and $\mathrm{Cr}(\mathrm{VI})$ Oxyanion Removal from Water by Advanced Oxidation/reduction Processes-a Review. Environ. Sci. Pollut. Res. 2019, 26, 2203-2227.

(45) Sun, M.; Zhang, G.; Qin, Y.; Cao, M.; Liu, Y.; Li, J.; Qu, J.; Liu, H. Redox Conversion of Chromium(VI) and Arsenic(III) with the Intermediates of Chromium(V) and Arsenic(IV) via AuPd/CNTs Electrocatalysis in Acid Aqueous Solution. Environ. Sci. Technol. 2015, 49, 9289-9297.

(46) Thilagan, J.; Kumar, A. V.; Rajasekaran, K.; Raja, C. Continuous Fixed Bed Column Adsorption of the Copper(II) Ions from Aqueous Solution by Calcium Carbonate Int. J. Res. Eng. Technol. 2015, 4, 413-418

(47) Patel, H. Fixed-bed column adsorption study: a comprehensive review. Appl. Water Sci. 2019, 9,45 . 

(a)

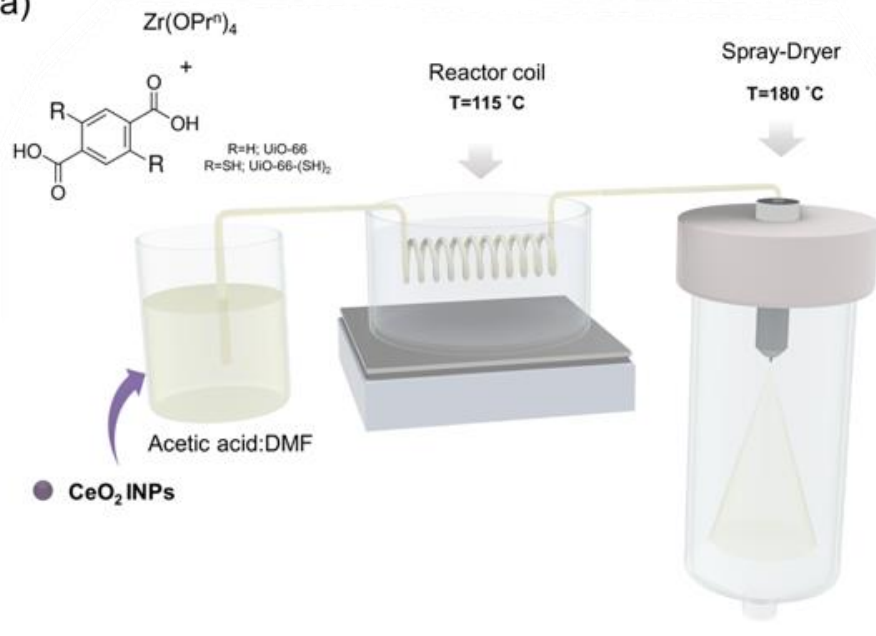

(b)

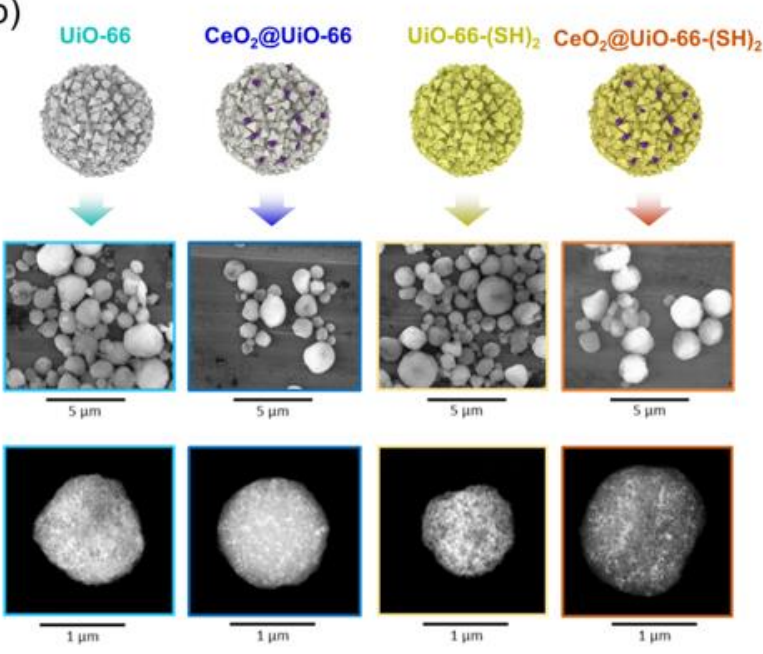

Fig. 1. a) Schematic of the continuous-flow spray-drying synthesis of MOF microbeads and iNP@MOF-Beads. b) Schematic (top), FE-SEM images (medium) and HAADF-STEM images (bottom) of MOF microbeads and iNP@MOF-Beads.
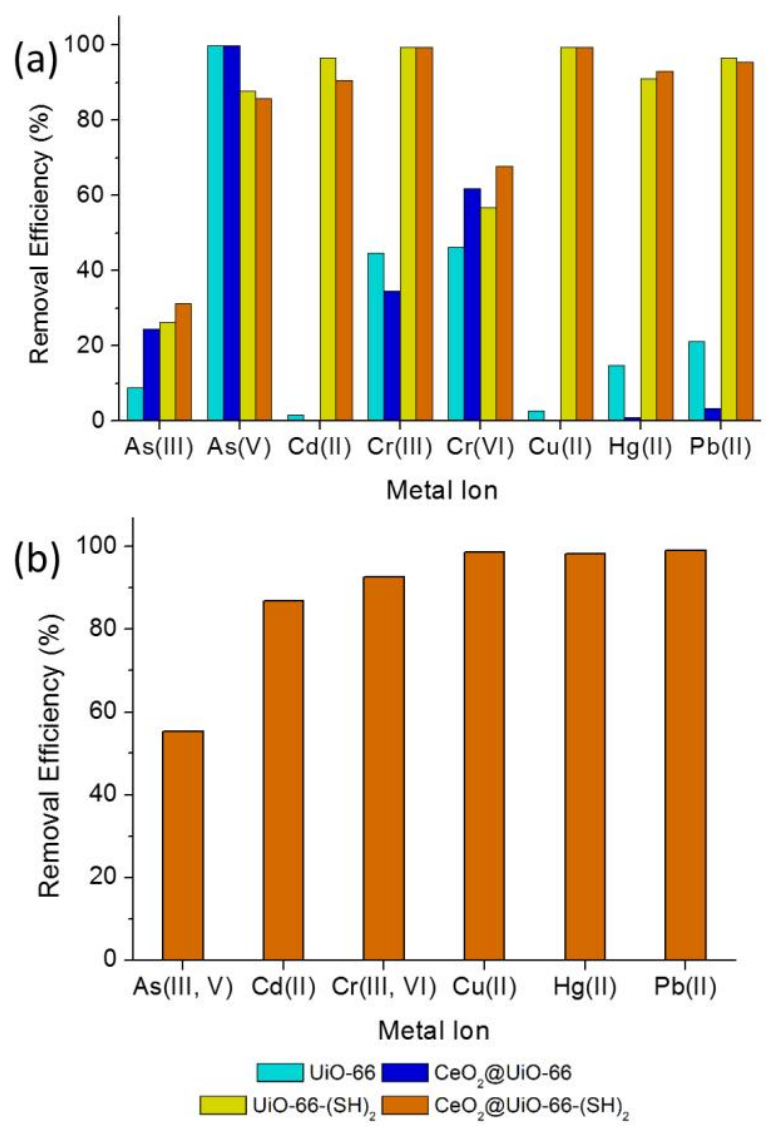

Fig. 2. a) Single-metal removal efficiency for UiO-66 (cyan),

$\mathrm{CeO}_{2} @$ UiO-66 (blue), UiO-66(SH) ${ }_{2}$ (yellow) and $\mathrm{CeO}_{2} @ U i O-66-$

$(\mathrm{SH})_{2}$ (orange). b) Multiple-metal removal efficiency for

$\mathrm{CeO}_{2} @ \mathrm{UiO}-66-(\mathrm{SH})_{2}$. 
(a)

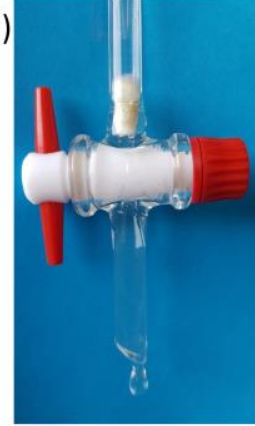

(b)

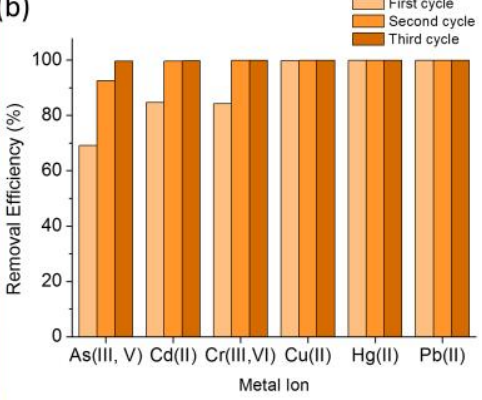

Fig. 3. a) Photograph of the continuous-flow column setup. b) Multiple- metal removal efficiency for the column containing

$\mathrm{CeO}_{2} @ U i O-66-(\mathrm{SH})_{2}$ as packing material. In this experiment, an aqueous solution (pH 5) of $\mathrm{As}(\mathrm{III}), \mathrm{As}(\mathrm{V}), \mathrm{Cd}(\mathrm{II}), \mathrm{Cr}(\mathrm{III}), \mathrm{Cr}(\mathrm{VI})$,

$\mathrm{Cu}(\mathrm{II}), \mathrm{Pb}$ (II) and $\mathrm{Hg}$ (II) (100 ppb each) was passed through the column three times. 

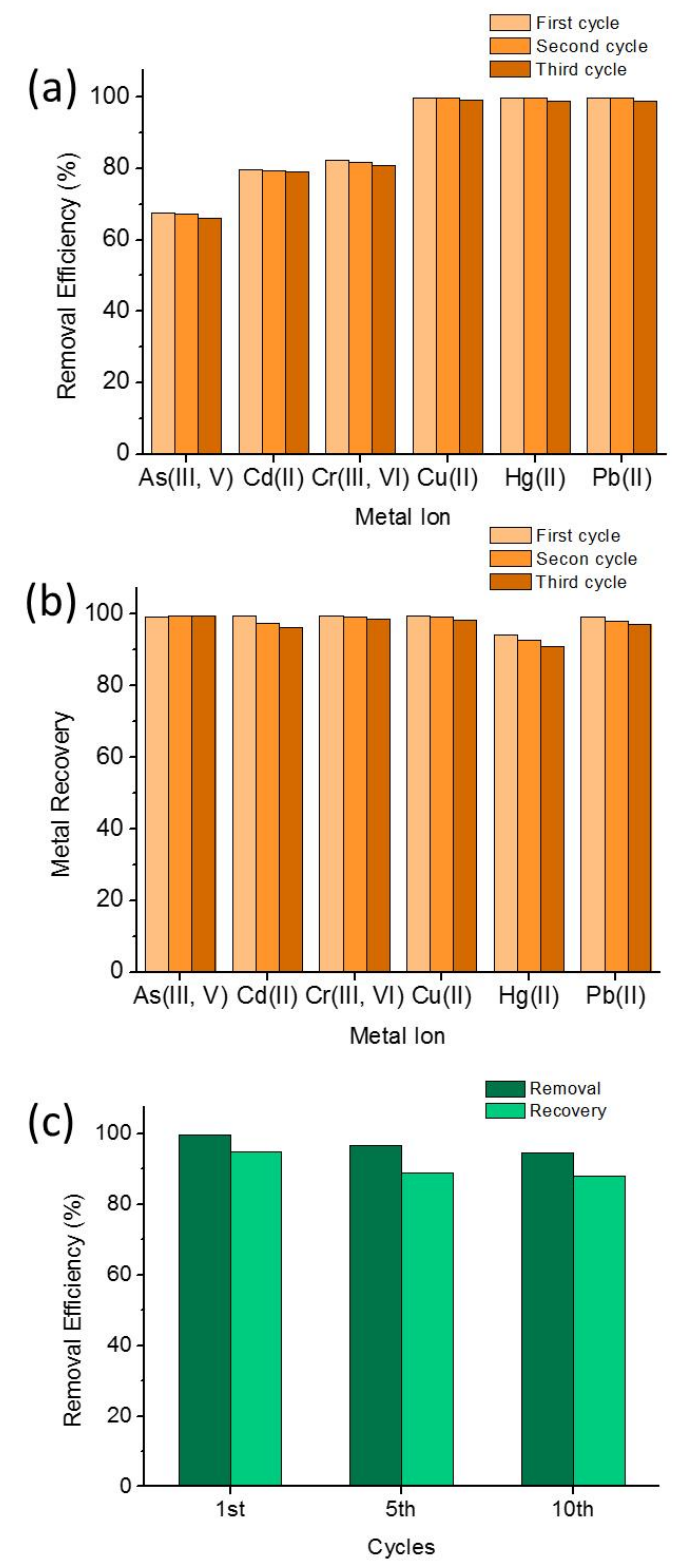

Fig. 4. (a,b) Multiple-metal removal efficiency (a) and recovery (b, regeneration) for the column after three adsorption/desorption cycles. (c) $\mathrm{Hg}$ (II) removal efficiency and recovery (regeneration) for the column after ten cycles of sequential adsorption/desorption steps. The adsorption step comprised passing through the column, $10 \mathrm{~mL}$ of water containing each metal-ion pollutant $(100 \mathrm{ppb})$. The desorption step comprised passing through the column, $100 \mathrm{~mL}$ of $250 \mathrm{mM}$ aq. $\mathrm{H}_{2} \mathrm{PO}_{4}^{-}(\mathrm{pH}=5)$. 
(a)

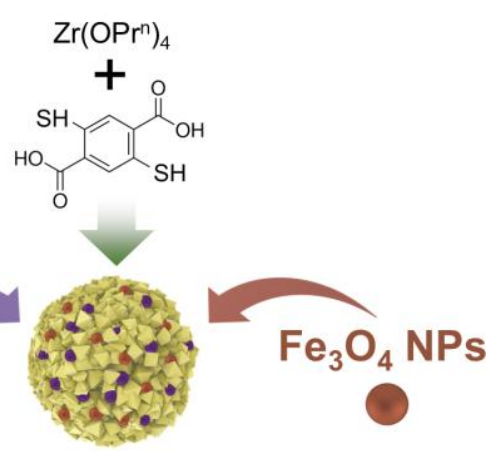

(b) $\quad \mathrm{CeO}_{2} / \mathrm{Fe}_{3} \mathrm{O}_{4} @ U i O-66-(\mathrm{SH})_{2}$
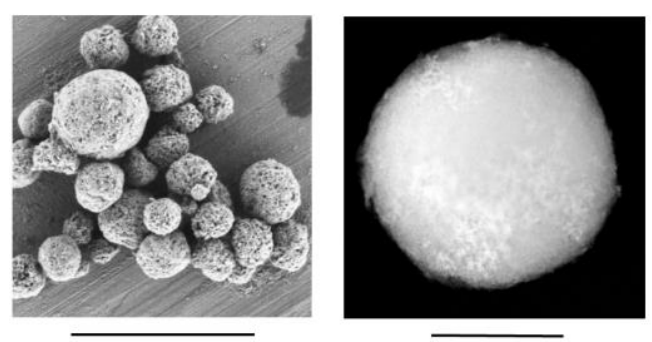

$5 \mu \mathrm{m}$

$1 \mu \mathrm{m}$

(c)

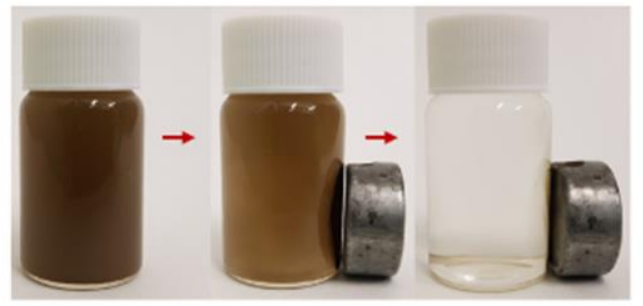

(d)

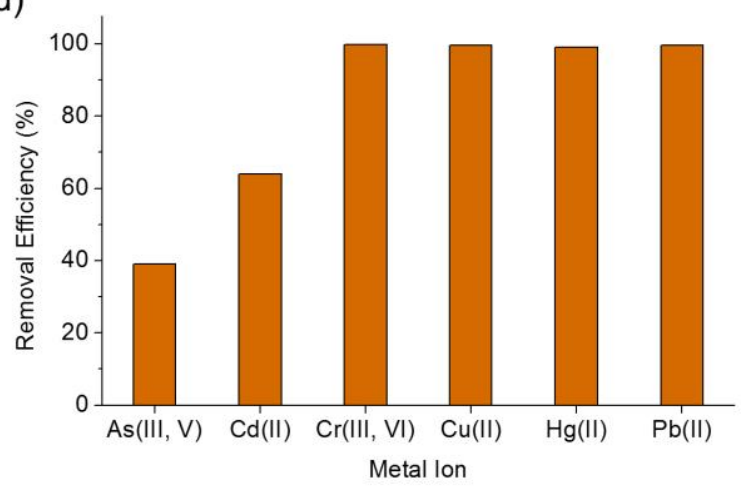

Fig. 5. a) Schematic of the synthesis of $\mathrm{CeO}_{2} / \mathrm{Fe}_{3} \mathrm{O}_{4} @ U i O-66$ $(\mathrm{SH})_{2}$. b) FE-SEM images (left) and HAADF-STEM images (right) of $\mathrm{CeO}_{2} / \mathrm{Fe}_{3} \mathrm{O}_{4} @ U i O-66-(\mathrm{SH})_{2}$. C) Photograph of a dispersion of $\mathrm{CeO}_{2} / \mathrm{Fe}_{3} \mathrm{O}_{4} @ U i \mathrm{O}-66-(\mathrm{SH})_{2}$ microbeads before (left) and after (middle) approach of a neodymium magnet, and after complete magnetic recovery (5 minutes in contact with the magnet; right). d) Multiple-metal removal efficiency for magnetically-recovered $\mathrm{CeO}_{2} / \mathrm{Fe}_{3} \mathrm{O}_{4} @ U i \mathrm{O}-66-(\mathrm{SH})_{2}$. 
Table 1. Results of metal-adsorption experiments (at $\mathrm{pH}=5$ and at the natural $\mathrm{pH}$ for each river), showing the maximum heavy-metal concentration permitted by WHO standards. The values marked with "*“ correspond to adsorption by $\mathrm{CeO}_{2} @ U \mathrm{UiO}-66$.

\section{Buringanga}

\begin{tabular}{ccccccccccc}
\cline { 2 - 11 } & \multicolumn{3}{c}{ Adsorption $\mathrm{pH}=5$} & \multicolumn{3}{c}{ Adsorption $\mathrm{pH}=6,6$} & \multicolumn{2}{c}{ Continuous flow $\mathrm{pH}=6,6$} \\
\hline $\begin{array}{c}\text { Metal } \\
\text { pollutant }\end{array}$ & $\begin{array}{c}\text { Before } \\
(\mathrm{ppb})\end{array}$ & $\begin{array}{c}\text { After } \\
(\mathrm{ppb})\end{array}$ & $\begin{array}{c}\text { Removed } \\
(\%)\end{array}$ & $\begin{array}{c}\text { Before } \\
(\mathrm{ppb})\end{array}$ & $\begin{array}{c}\text { After } \\
(\mathrm{ppb})\end{array}$ & $\begin{array}{c}\text { Removed } \\
(\%)\end{array}$ & $\begin{array}{c}\text { Before } \\
(\mathrm{ppb})\end{array}$ & $\begin{array}{c}\text { After } \\
(\mathrm{ppb})\end{array}$ & $\begin{array}{c}\text { Removed } \\
(\%)\end{array}$ & $\begin{array}{c}\text { WHO } \\
\text { standards } \\
(\mathrm{ppb})\end{array}$ \\
\hline$C d(I I)$ & 67 & 23 & $65 \%$ & 66 & 1.3 & $98 \%$ & 66 & 0.3 & $99 \%$ & 3 \\
$C r(I I I)$ & 114 & 1.1 & $99 \%$ & 105 & 33 & $69 \%$ & 105 & 11 & $90 \%$ & 50 \\
$C u(I I)$ & 249 & 10 & $96 \%$ & 243 & 2.1 & $99 \%$ & 243 & 0.9 & $99 \%$ & 2000 \\
$P b(I I)$ & 95 & $<0.25$ & $99 \%$ & 98 & $<0.25$ & $99 \%$ & 98 & $<0.25$ & $99 \%$ & 10
\end{tabular}

\section{Bone}

\begin{tabular}{|c|c|c|c|c|c|c|c|c|c|c|}
\hline \multirow[b]{2}{*}{$\begin{array}{c}\text { Metal } \\
\text { pollutant }\end{array}$} & \multicolumn{3}{|c|}{ Adsorption $\mathrm{pH}=5$} & \multicolumn{3}{|c|}{ Adsorption $\mathrm{pH}=7,5$} & \multicolumn{3}{|c|}{ Continuous-flow $\mathrm{pH}=7,5$} & \multirow[b]{2}{*}{$\begin{array}{c}\text { WHO } \\
\text { standards } \\
(\mathrm{ppb})\end{array}$} \\
\hline & $\begin{array}{c}\text { Before } \\
(\mathrm{ppb})\end{array}$ & $\begin{array}{l}\text { After } \\
(\mathrm{ppb})\end{array}$ & $\begin{array}{l}\text { Removed } \\
(\%)\end{array}$ & $\begin{array}{c}\text { Before } \\
(\mathrm{ppb})\end{array}$ & $\begin{array}{l}\text { After } \\
(\mathrm{ppb})\end{array}$ & $\begin{array}{c}\text { Removed } \\
(\%)\end{array}$ & $\begin{array}{r}\text { Before } \\
(\mathrm{ppb})\end{array}$ & $\begin{array}{l}\text { After } \\
(\mathrm{ppb})\end{array}$ & $\begin{array}{c}\text { Removed } \\
(\%)\end{array}$ & \\
\hline$A s(V)$ & 122 & 109 & $11 \%$ & 122 & $\begin{array}{c}84 \\
46^{*}\end{array}$ & $\begin{array}{c}31 \% \\
62 \% *\end{array}$ & 122 & 18 & $86 \%$ & 10 \\
\hline$H g(I I)$ & 178 & 2.5 & $99 \%$ & - & - & - & - & - & - & 6 \\
\hline$P b(I I)$ & 165 & 1.4 & $99 \%$ & 157 & 1.6 & $99 \%$ & 157 & 4.6 & $99 \%$ & 10 \\
\hline
\end{tabular}

Sarno

\begin{tabular}{|c|c|c|c|c|c|c|c|c|c|c|}
\hline \multirow[b]{2}{*}{$\begin{array}{c}\text { Metal } \\
\text { pollutant }\end{array}$} & \multicolumn{3}{|c|}{ Adsorption $\mathrm{pH}=5$} & \multicolumn{3}{|c|}{ Adsorption $\mathrm{pH}=7,5$} & \multicolumn{3}{|c|}{ Continuous-flow $\mathrm{pH}=7,2$} & \multirow[b]{2}{*}{$\begin{array}{c}\text { WHO } \\
\text { standards } \\
\text { (ppb) }\end{array}$} \\
\hline & $\begin{array}{l}\text { Before } \\
\text { (ppb) }\end{array}$ & $\begin{array}{l}\text { After } \\
(\mathrm{ppb})\end{array}$ & $\begin{array}{c}\text { Removed } \\
(\%)\end{array}$ & $\begin{array}{l}\text { Before } \\
\text { (ppb) }\end{array}$ & $\begin{array}{l}\text { After } \\
(\mathrm{ppb})\end{array}$ & $\begin{array}{c}\text { Removed } \\
(\%)\end{array}$ & $\begin{array}{c}\text { Before } \\
(\mathrm{ppb})\end{array}$ & $\begin{array}{l}\text { After } \\
(\mathrm{ppb})\end{array}$ & $\begin{array}{c}\text { Removed } \\
(\%)\end{array}$ & \\
\hline$A s(I I I)$ & 0.9 & 0.5 & $45 \%$ & 0.9 & 0.4 & $55 \%$ & 0.9 & $<0.25$ & $99 \%$ & 10 \\
\hline $\operatorname{Cr}(V I)$ & 11 & 7.7 & $30 \%$ & 11 & 6.9 & $37 \%$ & 11 & $<0.25$ & $99 \%$ & 50 \\
\hline$C u(I I)$ & 3.2 & $<0.25$ & $99 \%$ & 3.2 & $<0.25$ & $99 \%$ & 3.2 & $<0.25$ & $99 \%$ & 2000 \\
\hline
\end{tabular}

